\title{
Screening for Cold Tolerant Cactus Species (Opuntia ficus-indica) for West Asia Region
}

\author{
M. Louhaichi, S. Hassan and S. Ate \\ International Center for Agricultural \\ Research in the Dry Areas (ICARDA) \\ Amman \\ Jordan
}

\author{
A. Nefzaoui \\ International Center for Agricultural Research in \\ the Dry Areas (ICARDA), North Africa Program \\ Tunis \\ Tunisia
}

Keywords: barbary fig, prickly pear cactus, livestock feed, freezing tolerance, semi-arid ecosystem, environmental adaptation

\begin{abstract}
The identification of the cold tolerant Opuntia species to increase their cultivation in West Asia region where the cold winter conditions limit their adaptation is the primary yet the most critical step. The International Center for Agricultural Reserach in the Dry Areas (ICARDA) imported a total of 40 accessions of Opuntia ficus-indica from various regions of Latin America, North Africa, and Southern Europe. The mother cladodes from each accession was transplanted to the field at Tel Hadya research station in Aleppo (Syria) either on the 10 November 2011 (fall) or on the 14 April 2012 (spring) and their pad production and survival rates were recorded in 2012 and 2013. Significant differences in cold/freezing tolerance and pad production among tested Opuntia ficus-indica accessions were detected. Three accessions from the top five were those imported from Italy: "Trunzara yellow San Cono", "RSS Rossa San spate" and "M1 Gialla di Macomer". On the other hand, "CARTHA-73058" that was imported from Tunisia and "Conlea Rubescens, Conlea-L19" from Algeria had severe tissue damages. Averaged across the years, the accessions that were planted in spring produced 8.7 more pads compared to those were planted in autumn indicating that spring planting provides more conducive conditions for more successful establishment of cactus in West Asia region.
\end{abstract}

\section{INTRODUCTION}

Roughages from the degraded natural resources are the main source of livestock feed in West Asia and North Africa (WANA) region where large number of small ruminants have been reared under nomadic and semi-nomadic grazing systems (Ben Salem and Smith, 2008). This region is characterized by high population growth rate, low and variable rainfall, and water scarcity (Mulas and Mulas, 2004). Most of this area is overgrazed, and over $50 \%$ of the arid rangeland may have lost its vegetation since the 1950s (Le Houérou, 1992; Nefzaoui and Ben Salem, 2001). In some areas the damage has been irreversible leading to desertification (Sanlaville, 2000). Furthermore, the region is considered as one of the most susceptible to climate change impacts as significant increases in temperature and reductions in precipitation are expected (IPCC, 2007). The high dependence of resident communities on natural resources for their livelihoods and the poverty in many parts of the region will increase the vulnerability of affected people to respond to an increased incidence of drought and floods which will renders them less resilient to the impact of higher temperatures and lower and more variable precipitation (Seo and Mendelsohn, 2006).

Cacti that are adapted to seasonally hot (up to $50-55^{\circ} \mathrm{C}$ ) and drought conditions, contribute to the feed base and increasingly attracting to the livestock farmers in the arid and semiarid regions of the world. In particular, Opuntia species and in particular $O$. ficus-indica have been successfully grown in the marginalized areas for fodder as a standing buffer feed for drought periods, fruit and cochineal production of dye (carminic acid) and are widely used to prevent soil erosion and to combat desertification (Le Houérou 1996a; Gugliuzza et al., 2000; Felker and Inglese, 2003). It has been suggested 
that cacti as a CAM plant can be a significant part of the low input production systems in the semiarid zones of the developing countries where the productivity of $\mathrm{C} 3$ and $\mathrm{C} 4$ crops is restricted by the amount and the distribution of rain (Mondragon-Jacobo, 1999; Nefzaoui 2004). The increased use of cacti for forage and fruit will high likely to help reducing the feed gap for livestock and contribute to the food security and diversify the income source of resource poor farmers in marginalized areas of the West Asia region (Nefzaoui and Ben Salem, 2000). In addition, due to its ability to store carbon dioxide as organic acids through its unique CAM metabolism, greater potential exist for cacti than $\mathrm{C} 3$ crops to respond to the increased levels of atmospheric $\mathrm{CO}_{2}$ concentration (Nobel, 2002).

Despite their great capacity for adaptation and their ability to grow in degraded, infertile soils which are not favourable for the production of most common crops, cacti do not appear to be widely cultivated in West Asia where probably its distribution is restricted primarily by the freezing events that occur during winter seasons (Le Houérou, 1996b). Cacti are not usually native to the cold regions that often experience sub-zero temperatures (Levitt, 1980) that limits their latitudinal and elevational distribution as most cacti species have been reported to have irreversible tissue damage when being exposed to air temperature below -5 to $-10^{\circ} \mathrm{C}$, exceeding $1 \mathrm{~h}$ (Nobel, 1988; Goldstein and Nobel, 1994). However, Loik and Nobel (1993) reported that cold hardy species of cacti with varying in freezing tolerance such as Opuntia fragilis can withstand the negative impacts of sub-zero temperatures for several weeks in North America indicating that some cacti species can be successfully grown in the areas of the world that experiences harsh winter conditions. This suggests that genotypes that may have the traits of cold tolerance may provide opportunities to increase the cultivation of cacti in the colder regions or at higher elevations. Therefore research and adaptation studies, including germplasm exchange and evaluation should be undertaken to identify the adaptability of the cacti lines that may successfully adapt to cold temperatures in West Asia.

Thus a screening study to evaluate the cold tolerance of cacti accessions acquired from various regions of the world was conducted with the main objectives to explore genetic resources with potential genes for adaptation to the adverse effects of climate change particularly night freezing temperature during winter season and to evaluate agronomic practices such as date of transplantation on cactus establishment and vigour.

\section{MATERIAL AND METHODS}

\section{Study Site}

The experiment was carried out in the research station of the International Center for Agricultural Research in the Dry Areas (ICARDA) $\left(36^{\circ} 01^{\prime} \mathrm{N}, 36^{\circ} 56^{\prime} \mathrm{E}, 284 \mathrm{~m}\right.$ a.s.l.) located at $30 \mathrm{~km}$ south of Aleppo, northern Syria. The soil contains 20-30\% calcium carbonate, the $\mathrm{pH}$ range of 7.9-8.2. The parent material is limestone. The clay content, at nearly $65 \%$ of the total soil texture, is a smectite mineral. Soil has relatively low soil organic matter, less than $2 \%$. The average maximum daily air temperatures ranged from $10.5^{\circ} \mathrm{C}$ in winter 2012 to $39.6^{\circ} \mathrm{C}$ in summer 2012 while the average minimum daily air temperatures were between $0.5^{\circ} \mathrm{C}$ in winter 2011 and $23.1^{\circ} \mathrm{C}$ in summer 2011 (Table 1). The lowest daily air temperature recorded was $-5.6^{\circ} \mathrm{C}$ in December 2011. The air temperature went down below $-5^{\circ} \mathrm{C}$ only in one day in December 2011 and one day in March 2012 (Table 2).

\section{Plant Materials}

A total of 40 accessions of Opuntia ficus-indica (OFI) pads were imported from various regions of Latin America, Africa, and Europe to ICARDA's research station, Aleppo, Syria in 2011. Mother cladodes from each accession were transplanted to the field gene-bank during the fall of 2011 and spring of 2012. The pads were stored under shade for 15 days prior to planting in spring. The remaining pads were planted in pots and preserved in the greenhouse for 90 days before planting them in autumn. The row space 
and the distance between each pad were $3 \times 2 \mathrm{~m}$. The pads were irrigated as needed during the establishment phase.

\section{Measurements and Statistical Analyses}

Cladodes were naturally subjected to ambient temperature and freezing events during the experimental period (Fig. 1). Assessment of frost damage (survival of new cladodes) was conducted by means of visual symptoms (color turned brown) during the month of August 2012 and 2013. During the same time, the growth of the accessions was assessed by counting the number of new cladodes. General linear model procedure was used for statistical analysis through SAS software (SAS, 2009), using completely randomized design. For the purpose of comparison between the two transplanting dates, paired t-test were employed. Duncan's multiple tests were applied for comparison of means.

\section{RESULTS AND DISCUSSION}

Opuntia ficus-indica is the cactus species with the highest economic importance worldwide. The Opuntia ficus-indica accessions also differed significantly $(\mathrm{P}<0.01)$ in their inherent cold/freezing tolerance in both years (Fig. 1). Three accessions from the top five were those imported from Italy: "Trunzara yellow San Cono", "RSS Rossa San sperate" and "M1 Gialla di Macomer". On the other hand, "CARTHA-73058" that was imported from Tunisia and "Conlea Rubescens, Conlea-L19" from Algeria had severe tissue damages (Fig. 1). It was also observed that the young cladodes were more vulnerable in all accessions.

Results of the independent sample t-test analysis for evaluation of the planting date (fall versus spring) revealed significant differences (Fig. 2) for the pad production of Opuntia ficus-indica accessions. Pad production of cacti accessions in spring planting $(13.7 \pm 5.9)$ was significantly higher $(\mathrm{P}<0.01)$ than fall planting $(5.6 \pm 7.3)$ in $2012 ; \mathrm{t}$ $(39)=5.43$. Similar results were obtained in 2013 when spring planting $(15.3 \pm 7.2)$ resulted in significantly more $(\mathrm{P}<0.01)$ number of newly produced pads compared to fall planting $(6.1 \pm 8.2)$; $(39)=5.34$. These results indicates that spring planting may provide conditions more conducive for successful establishment and higher chance of survival for cacti in West Asia region. In addition, cactus pads that were planted in the fall were probably more susceptible as their root system has not been fully developed to withstand the cold winter conditions.

\section{CONCLUSION}

The genus Opuntia is probably the most successful cactus genus according to its distribution, dispersal traits and multiplication processes. Cactus is an important forage option to semi-arid regions. Fiting the right plant to the semi-arid environment makes more sense than changing the environment. Thus assessing adaptation of cactus accessions across a wide range of climates and agro-ecosystems is needed. In order to have more representative sites covering main agro-ecological production systems in West Asia, additional sites were selected in Jordan and Lebanon.

It is concluded that a number of Opuntia ficus-indica accessions that were used in this study have shown promising resistance to cold in Syria. These preliminary results should be used with cautions until further testing is complete. The success of establishment of cold tolerant Opuntia ficus-indica accessions may be increased through spring planting. The trials established so far have looked only at the adaptation of Opuntia ficus-indica based on the phonological traits. Future research will focus on key traits responsible for resistance to cold (frost damage) using biotechnology techniques.

\section{ACKNOWLEDGEMENTS}

This work was sponsored by the CGAIR Agriculture and Food Security (CCAFS) and the Center for Agricultural Research in the Dry Areas (ICARDA). We are grateful to the support of the FAO-ICARDA Cactusnet for facilitating provision of plant materials. 


\section{Literature Cited}

Ben Salem, H. and Smith, T. 2008. Feeding strategies to increase small ruminant production in dry environments. Small Rumin Res. 77:174-194.

Felker, P. and Inglese, P. 2003. Short-term and long-term research needs for Opuntia ficus-indica (L.) Mill. Utilization in arid areas. J. Prof. Assoc. Cactus Dev. 5:131-152.

Goldstein, G. and Nobel, P.S. 1994. Water relations and low-temperature acclimation for cactus species varying in freezing tolerance. Plant Physiol.104:675-681.

Gugliuzza, G., La Mantia, T. and Inglese, P. 2000. Fruit load and cladodes nutrient concentrations in cactus pear. Acta Hort. 581:221-224.

IPCC 2007. p.996. In: S. Solomon, D. Qin, M. Manning, Z. Chen, M. Marquis, K.B. Averyt, M. Tignor and H.L. Miller (eds.), Climate Change 2007: The Physical Science Basis. Contribution of Working Group I to the Fourth Assessment Report of the Intergovernmental Panel on Climate Change. Cambridge University Press, Cambridge, United Kingdom and New York, NY, USA.

Le Houérou, H.N. 1992. The role of saltbushes (Atriplex spp) in arid land rehabilitation in the Mediterranean basin: a review. Agrofor. Syst 18:107-148.

Le Houérou, H.N. 1996a. The role of cacti (Opuntia spp.) in erosion control, land reclamation, rehabilitation and agricultural development in the Mediterranean Basin. $\mathrm{J}$ Arid Environ. 33:135-159.

Le Houérou, H.N. 1996b. Utilization of Fodder Trees and Shrubs (TRUBS) in the Arid and Semi-Arid Zones of Western Asia and Northern Africa (WANA): History and Perspectives. A Review. Hamamat, Tunisia: ICARDA/CIHEAM.

Levitt, J. 1980. Responses of Plants to Environmental Stresses. Second edition. Volume 1. Chilling, Freezing and High Temperature Stresses. Academic Press, New York, USA.

Loik, M.E. and Nobel, P.S. 1993. Freezing tolerance and water relations of Opuntia fragilis from Canada and the United States. Ecology 74:1722-1732.

Mondragon-Jacobo, C. 1999. Low input agricultural systems based on cactus pear for subtropical semiarid environments. p.367-372. In: J. Janick (ed.), Perspectives on New Crops and New Uses. ASHS Press, Alexandria, VA.

Mulas, M. and Mulas, G. 2004. The strategic use of Atriplex and Opuntia to combat desertification. Technical report, University of Sassari, Desertification Research Group.

Nefzaoui, A. 2004. Rangeland improvement and management options in the arid environment of Central and South Tunisia. Options Méditerranéennes, Série A. 59:1525.

Nefzaoui, A. and Ben Salem, H. 2000. Opuntia spp.: a strategic fodder and efficient tool to combat desertification in the WANA region. FAO International Cactus Pear Network Newsletter.

Nefzaoui, A. and Ben Salem, H. 2001. Opuntia spp. a strategic fodder and efficient tool to combat desertification in the WANA region. In: C. MondragonJacobo and S. PerezGonzalez (eds.), Cactus as Forage. FAO Plant Production and Protection Paper 169. FAO, Rome.

Nobel, P.S. 1988. Environmental Biology of Agaves and Cacti. Cambridge University Press, New York.

Nobel, P.S. 2002. Cacti: Biology and Uses. University of California, Berkeley, California, USA.

Sanlaville, P. 2000. Environment and development. p.6-16. In: M. Mundy and B. Musallam (eds.), The Transformation of Nomadic Society in the Arab East, Chapter 1, Cambridge University Press.

SAS, 2009. SAS/STAT User's Guide, Version 9.2. SAS Institute, Cary, NC, USA.

Seo, S.N. and Mendelsohn, R. 2006. Climate change adaptation in Africa: a microeconomic analysis of livestock choice. Centre for Environmental Economics and Policy in Africa (CEEPA) Discussion Paper No. 19. University of Pretoria, Pretoria. 
$\underline{\text { Tables }}$

Table 1. Monthly rainfall, maximum and minimum mean daily air temperatures at Tel Hadya, Aleppo, Syria (2011-2013).

\begin{tabular}{|c|c|c|c|c|c|c|c|c|c|c|c|c|}
\hline \multirow[b]{2}{*}{ Month } & \multicolumn{4}{|c|}{$\begin{array}{l}\text { Mean of maximum daily air } \\
\text { temperatures }\left({ }^{\circ} \mathrm{C}\right)\end{array}$} & \multicolumn{4}{|c|}{$\begin{array}{l}\text { Mean of minimum daily air } \\
\text { temperatures }\left({ }^{\circ} \mathrm{C}\right)\end{array}$} & \multicolumn{4}{|c|}{ Rainfall (mm) } \\
\hline & 2011 & 2012 & 2013 & LTM* & 2011 & 2012 & 2013 & LTM* & 2011 & 2012 & 2013 & LTM* \\
\hline January & 13.0 & 10.5 & 13.1 & 11.7 & 2.5 & 2.6 & 1.6 & 1.6 & 40.8 & 120.3 & 47.9 & 31.0 \\
\hline February & 14.9 & 13.0 & 15.8 & 13.8 & 3.1 & 1.3 & 4.7 & 2.2 & 42.1 & 104.8 & 58.2 & 28.3 \\
\hline March & 19.3 & 16.1 & 20.0 & 18.2 & 4.0 & 2.8 & 5.0 & 4.3 & 24.4 & 33.5 & 10.2 & 31.0 \\
\hline April & 23.5 & 26.6 & 24.7 & 24.1 & 7.8 & 8.6 & 8.3 & 8.0 & 44.6 & 3.2 & 36.0 & 30.0 \\
\hline May & 28.6 & 29.3 & & 30.1 & 12.2 & 13.4 & & 12.1 & 10.1 & 4.6 & & 31.0 \\
\hline June & 34.6 & 37.4 & & 35.0 & 18.5 & 19.2 & & 17.7 & 0.5 & 2.5 & & 30.0 \\
\hline July & 38.9 & 39.6 & & 37.8 & 22.1 & 22.8 & & 21.7 & 0.0 & 0.0 & & 31.0 \\
\hline August & 38.2 & 38.4 & & 37.9 & 23.1 & 22.8 & & 21.9 & 0.0 & 0.0 & & 31.0 \\
\hline September & 35.0 & 36.1 & & 34.5 & 19.8 & 19.5 & & 17.6 & 0.7 & 0.0 & & 30.0 \\
\hline October & 27.2 & 28.8 & & 28.3 & 10.9 & 14.1 & & 12.4 & 21.6 & 32.7 & & 31.0 \\
\hline November & 15.8 & 21.0 & & 19.5 & 3.3 & 7.7 & & 6.0 & 96.1 & 30.7 & & 30.0 \\
\hline December & 12.8 & 14.5 & & 13.0 & 0.5 & 4.2 & & 2.8 & 68.6 & 140.0 & & 31.0 \\
\hline
\end{tabular}

LTM*: Long term means of air temperature and rainfall are for the period 1985-2012.

Table 2. Minimum air temperatures and number of days when the temperature was lower than $\leq 0$ and -5 at Tel Hadya, Aleppo, Syria (2011-2013).

\begin{tabular}{|c|c|c|c|c|c|c|c|c|c|}
\hline & \multicolumn{2}{|c|}{2011} & \multicolumn{4}{|c|}{2012} & \multicolumn{3}{|c|}{2013} \\
\hline & Nov & Dec & Jan & Feb & Mar & Dec & Jan & Feb & Mar \\
\hline Minimum air temperature $\left({ }^{\circ} \mathrm{C}\right)$ & -3.3 & -5.6 & -5 & -3 & -5.5 & -2.5 & -3.2 & -0.3 & -4.5 \\
\hline Number of days $\leq 0^{\circ} \mathrm{C}$ & 6 & 15 & 8 & 14 & 7 & 6 & 13 & 2 & 4 \\
\hline Number of days $\leq-5^{\circ} \mathrm{C}$ & 0 & 1 & 0 & 0 & 1 & 0 & 0 & 0 & 0 \\
\hline
\end{tabular}




\section{Figures}

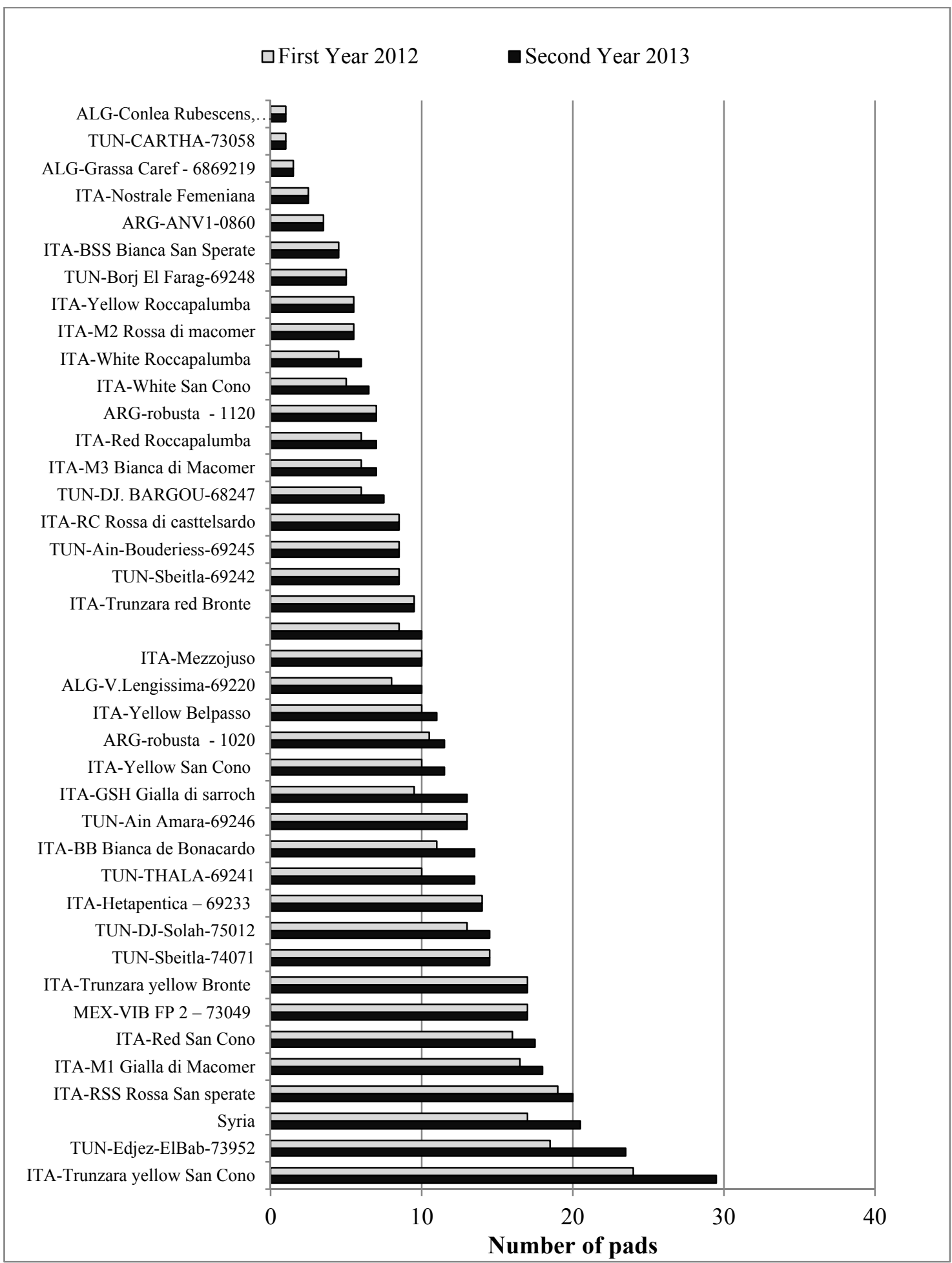

Fig. 1. Number of pads produced per accession in two growing seasons $(2012,2013)$. 


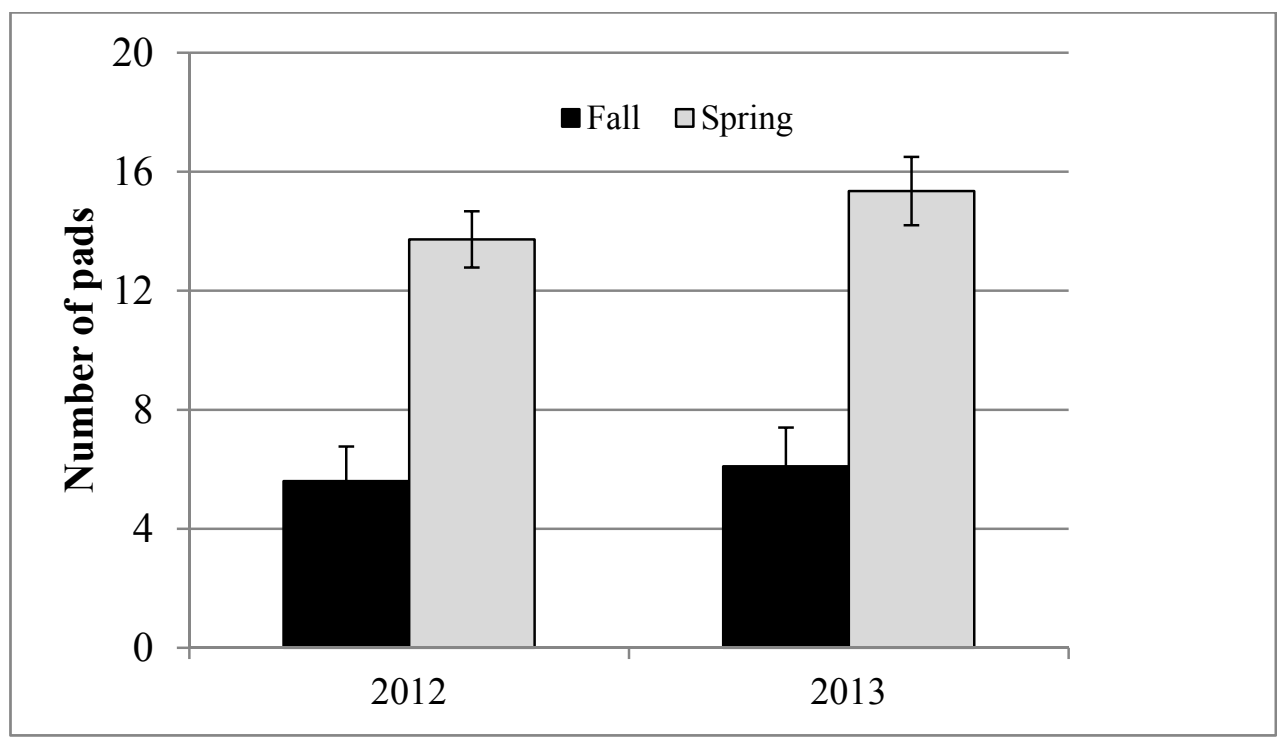

Fig. 2. Number of pads in fall and spring transplanting dates in two groing seasons 2012 and 2013. 
